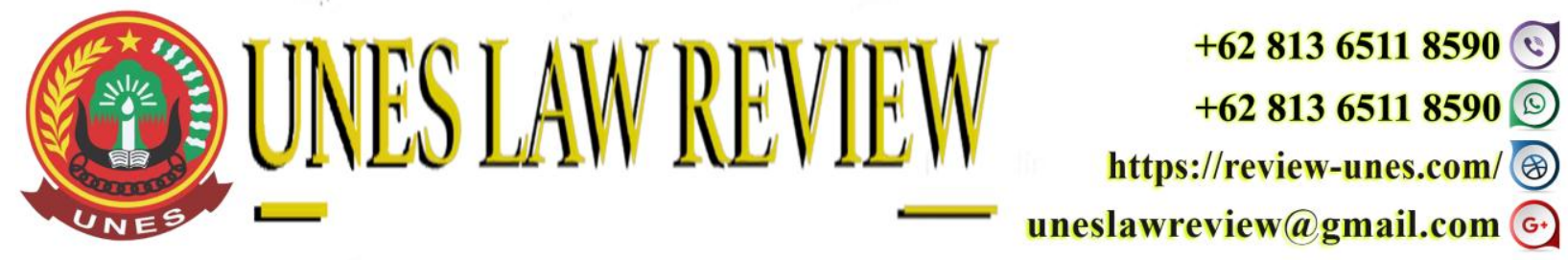

DOI: https://doi.org/10.31933/unesrev.v3i4

Diterima: 20/07/2021, Diperbaiki: 27/07/2021, Diterbitkan: 01/08/2021

\title{
PERAN PENYIDIK PANGKALAN TNI ANGKATAN LAUT DALAM PENANGGULANGAN PENCURIAN IKAN OLEH KAPAL IKAN ASING DI PERAIRAN NATUNA
}

\author{
Rama Arcan \\ Program Magister Ilmu Hukum, Universitas Ekasakti, Padang, Indonesia \\ Email: arcanrama82@gmail.com
}

Corresponding Author: Rama Arcan

\section{ABSTRACT}

Law Number 17 of 1985 concerning Ratification of the United Nations Convention on the Law of the Sea 1982 (UNCLOS 1982). Indonesia has sovereign rights to utilize, conserve and manage fish resources in the Indonesian Exclusive Economic Zone (ZEEI) and the high seas. The large number of natural resources contained in the sea makes it vulnerable to illegal exploitation and exploration by irresponsible parties. Anambas Islands Regency has a total of 255 islands located in the Natuna waters, the Tarempa Navy Base (Lanal) often gets foreign-flagged fishing boats caught illegally stealing fish caught carrying out patrols in the Natuna waters.

Keywords: Navy Investigators, Fish Theft, Foreign Ships and Natuna Waters Road

\begin{abstract}
ABSTRAK
Undang-Undang Nomor 17 Tahun 1985 tentang Pengesahan United Nations Convention on the Law of the Sea 1982 (UNCLOS 1982). Indonesia memiliki hak berdaulat (sovereign rights) untuk melakukan pemanfaatan, konservasi dan pengelolahan sumber daya ikan di Zona Ekonomi Eksklusif Indonesia (ZEEI) dan laut lepas. Banyaknya sumber daya alam yang terkandung di dalam laut menjadikan rawan dari eksploitasi dan eksplorasi illegal oleh pihak-pihak yang tidak bertanggung-jawab. Kabupaten Kepulauan Anambas memiliki total keseluruhan 255 pulau yang terlelak di wilayah perairan Natuna, Pangkalan TNI AL (Lanal) Tarempa sering kali mendapatkan kapal ikan berbendera asing kedapatan mencuri ikan secara illegal yang tertangkap sedang melaksanakan melaksanakan patroli dikawasan perairan Natuna.
\end{abstract}

Kata Kunci: Penyidik TNI AL, Pencurian Ikan, Kapal Asing dan Perairan Natuna 


\section{PENDAHULUAN}

Negara Indonesia secara geografis terletak di posisi silang dua benua Asia dan Australia, dan dua samudera Hindia dan Pasifik. Melihat sisi luas wilayah perairan, lautan, panjang garis pantai, dan letak geografis, Indonesia merupakan archipelagic state (negara kepulauan) terbesar di dunia, memiliki potensi sumber daya ikan yang besar. Sebagai negara kepulauan, hampir dua pertiga wilayahnya lautan, memiliki luas wilayah perairan 5.8 juta $\mathrm{Km}^{2}$, laut teritorial 3.1 juta $\mathrm{Km}^{2}$, ZEEI2.7 juta $\mathrm{Km}^{2}$, panjang garis pantai $81.000 \mathrm{Km}$, panjang base line $13.179 \mathrm{Km}$, memiliki \pm 17.499 pulau, dan terdapat lima pulau besar yaitu Sumatera, Jawa, Kalimantan, Sulawesi dan Irian Jaya (Papua) (Markas Besar TNI AL, 2006:7).

Pada tanggal 31 Desember 1985 Pemerintah meratifikasi Konvensi Perserikatan BangsaBangsa tentang Hukum Laut Tahun 1982 melalui Undang-Undang Nomor 17 Tahun 1985 tentang Pengesahan United Nations Convention on the Law of the Sea 1982 (UNCLOS 1982) maka secara yuridis formal wilayah perairan yurisdiksi nasional Indonesia menjadi sangat luas. Indonesia memiliki hak berdaulat (sovereign rights) untuk melakukan pemanfaatan, konservasi dan pengelolahan sumber daya ikan di Zona Ekonomi Eksklusif Indonesia (ZEEI) dan laut lepas yang dilaksanakan berdasarkan persyaratan atau standar ketentuan internasional (Djoko Tribawono, 2013:10).

ZEEI adalah jalur di luar dan berbatasan dengan laut wilayah Indonesia sebagaimana ditetapkan berdasarkan undang-undang yang berlaku tentang perairan Indonesia yang meliputi dasar laut, tanah di bawahnya dan air di atasnya dengan batas terluar 200 (dua ratus) mil laut diukur dari garis pangkal laut wilayah Indonesia. Di ZEEI, negara Indonesia mempunyai kewajiban untuk memberikan kesempatan terutama kepada negara tidak berpantai atau negara yang secara geografis tidak beruntung untuk turut serta memanfaatkan surplus dari jumlah tangkapan ikan yang diperbolehkan (I Made Pasek Diantha, 2002:16).

Banyaknya sumber daya alam yang terkandung di dalam laut menjadikan rawan dari eksploitasi dan eksplorasi illegal oleh pihak-pihak yang tidak bertanggung-jawab, utamanya penangkapan ikan secara illegal (illegal fishing) oleh kapal-kapal ikan berbendera asing dengan menggunakan peralatan-peralatan moderen di Wilayah Pengelolaan Perikanan Republik Indonesia (WPPRI). Modus operandi tindak pidana perikanan yang paling menonjol adalah transhipment di laut secara illegal (Fitiyad, 2007, 63). Transhipment ini merupakan tindak pidana yang dianggap sama melakukan kegiatan perikanan tanpa ijin.

Berdasarkan data Kementerian Kelautan dan Perikanan tahun 2011, potensi pendapatan sektor perikanan laut adalah Rp65 triliun dan terjadi illegal fishing. Sementara data audit BPK 2012 menemukan potensi pendapatan bila illegal fishing dihilangkan adalah Rp365 triliun. Artinya ada Rp 300 triliun potensi pendapatan Negara yang hilang (Nina Suartika, 2020).

Praktek illegal fishing untuk negara Indonesia dengan luas laut lebih dari 5 juta $\mathrm{km}^{2}$ memang bukan hal yang mudah untuk diatasi. Kend Sondakh (Kepala Staf Angkatan Laut 20022005) memasukkan pelanggaran hukum di laut sebagai bentuk ancaman karena berpotensi merusak perekonomian negara (Camelia Sukmawati, 2014:168). Untuk itu, pemerintah menyatakan perang terhadap illegal fishing, karena illegal fishing merupakan masalah serius 
yang harus segera ditanggulangi sebab sangat membahayakan kelestarian sumber daya dan merugikan secara ekonomi bagi Negara (Harian Umum Pelita, 2020).

Hal ini sejalan dengan apa yang telah disampaikan oleh Presiden Joko Widodo (Jokowi), menginstruksikan agar Tentara Nasional Indonesia Angkatan Laut (TNI AL) menenggelamkan ratusan kapal perikanan berbendera asing yang masuk ke perairan Indonesia secara illegal. Menurut Presiden illegal fishing yang dilakukan oleh kapal asing selama ini telah merugikan negara cukup besar. Laporan menyebutkan setiap hari 5.400 kapal yang masuk perairan Indonesia tanpa izin (Rarasati Syarief, 2014:5).

TNI AL sebagai komponen utama pertahanannegara matra laut dituntut kesiapannya dalam menghadapi dan mengantisipasi berbagai bentuk ancaman yang dapat mengganggu keamanan dan kedaulatan Negara Kesatuan Republik Indonesia (NKRI) (Untung Suropati, 2014:43). TNI AL sebagai bagian dari TNI, sesuai amanat Undang-Undang Nomor 34 Tahun 2004 tentang Tentara Nasional Indonesia, dalam Pasal 9 memiliki tugas sebagai berikut :

1. Melaksanakan tugas TNI matra laut di bidang pertahanan;

2. Menegakkan hukum dan menjaga keamanan di wilayah laut yurisdiksi nasional sesuai dengan ketentuan hukum nasional dan internasional yang telah diratifikasi;

3. Melaksanakan tugas diplomasi Angkatan Laut dalam rangka mendukung kebijakan politik luar negeri yang ditetapkan oleh pemerintah;

4. Melaksanakan tugas TNI dalam pembangunan dan pengembangan kekuatan matra laut; dan

5. Melaksanakan pemberdayaan wilayah pertahanan laut.

Berdasarkan Pasal 69 Undang-Undang Nomor 45 Tahun 2009 tentang Perubahan Atas Undang-Undang Nomor 31 Tahun 2004 tentang Perikanan, menyatakan sebagai berikut :

1. Kapal pengawas perikanan berfungsi melaksnakan pengawasan dan penegakan hukum di bidang perikanan dalam wilayah pengelolaan perikanan Negara Republik Indonesia .

2. Kapal pengawas perikanan sebagaimana dimaksud pada ayat (1), dapat dilengkapi dengan senjata api.

3. Kapal pengawas perikanan dapat menghentikan, memeriksa, membawa, dan menahan kapal yang diduga atau patut diduga melakukan pelanggaran di wilayah pengelolaan perikanan Negara Republik Indonesia ke pelabuhan terdekat untuk diproses lebih lanjut.

4. Dalam melaksanakan fungsi sebagaimana dimaksud pada ayat (1), penyidik dan/atau pengawas perikanan dapat melakukan tindakan khusus berupa pembakaran dan/atau penenggelaman kapal perikanan yang berbendera asing berdasarkan bukti permulaan yang cukup.

Ketentuan Pasal 69 ayat (4) UU Nomor 45 Tahun 2009 secara substansi dan redaksional menimbulkan penafsiran dalam penerapannya. Apakah tindakan khusus itu hanya diberikan kepada penyidik PPNS Perikanan atau termasuk penyidik Perwira TNI AL dan penyidik Polri sebab penerapan Pasal 69 ayat (4) UU Nomor 45 Tahun 2009 semata-mata dalam konteks pelaksanaan fungsi kapal pengawas perikanan bukan dilaksanakan oleh kapal-kapal milik TNI AL dan atau Polri karena mereka bukanlah kapal pengawas perikanan. Berdasarkan ketentuan 
Pasal 73 ayat (1) UU Nomor 45 Tahun 2009, penyidik tindak pidana di bidang perikanan di wilayah pengelolaan perikanan Negara Republik Indonesia dilakukan oleh Penyidik Pegawai Negeri Sipil Perikanan, Penyidik Perwira TNI AL, dan/atau Penyidik Kepolisian Negara Republik Indonesia .

Tugas menegakkan hukum dan menjaga keamanan mengandung arti bahwa TNI AL melaksanakan segala bentuk kegiatan yang berhubungan dengan penegakan hukum di laut sesuai dengan kewenangannya (constabulary function) yang berlaku secara universal dan sesuai dengan ketentuan perundang-undangan yang berlaku untuk mengatasi ancaman tindakan kekerasan, ancaman navigasi, serta pelanggaran hukum di wilayah laut yurisdiksi nasional. Penegakan hukum yang dilaksanakan oleh TNI AL, terbatas dalam lingkup pengejaran, penangkapan, penyelidikan dan penyidikan perkara yang selanjutnya diserahkan kepada Kejaksaan.

Secara umum dalam melaksanakan penegakan kedaulatan dan hukum di laut TNI AL dan khususnya dalam hal ini Pangkalan TNI AL (Lanal) Tarempa terletak di Kabupaten Kepulauan Anambas (KKA) Propinsi Kepulauan Riau (Kepri) melaksanakan tugas pokok dan fungsi pangkalan dalam menjaga kedaulatan Negara dimana berbatasan langsung dengan Negara luar seperti Malaysia, Thailand, Vietnam dan Kamboja, Pangkalan TNI AL (Tarempa) dihadapkan dengan hadirnya kapal ikan asing yang melaksanakan kegiatan illegal fisting di perairan yurisdiksi Indonesia khususnya di perairan laut Natuna, selanjutnya dalam melaksanakan tugas pokok dan fungsi pangakalan TNI AL (Lanal) Tarempa memiliki keterbatasan unsur kapal untuk patroli dan personel yang terbatas untuk melaksanakan patroli mengingat Kabupaten Kepulauan Anambas (KKA) memiliki banyak pulau baik pulau-pulau besar maupun pulau-pulau kecil dimana total keseluruhan 255 pulau yang terlelak di wilayah perairan Natuna, Pangkalan TNI AL (Lanal) Tarempa sering kali mendapatkan kapal ikan berbendera asing kedapatan mencuri ikan yang tertangkap oleh Kapal Republik Indonesia (KRI) sedang melaksanakan melaksanakan patroli dikawasan perairan Natuna.

Berdasarkan uraian tersebut diatas, maka perlu adanya perumusan masalah guna mempermudah pembahasan selanjutnya. Adapun permasalahan yang akan dikemukakan adalah sebagai berikut;

1. Bagaimana peran penyidik Pangkalan TNI Angkatan Laut Tarempa dalam penanggulangan pencurian ikan oleh kapal ikan asing di Perairan Natuna?

2. Apa kendala yang dihadapi dalam melaksanakan penanggulangan pencurian ikan oleh kapal asing di Perairan Natuna dan upaya mengatasinya?

\section{METODE PENELITIAN}

Berdasarkan pada masalah yang telah diuraikan diatas, maka Spesifikasi penelitian ini bersifat deskriptif analitis yaitu penelitian yang dilakukan untuk menggambarkan dan menguraikan objek penelitian atau masalah yang diteliti berupa kata-kata tertulis ataupun lisan dan perilaku orang-orang yang diamati (Soerjono Soekanto, 1984:51). Penelitian deskriptif analitis ini diharapkan mampu memecahkan masalah dengan cara memaparkan keadaan obyek penelitian yang sedang diteliti apa adanya berdasarkan fakta-fakta yang diperoleh pada saat 
penelitian dilakukan, (Hadari Nawawi, 1992:42) sehingga dengan metode ini akan dapat diperoleh data yang lebih tuntas, pasti, dan memberikan gambaran secara mendalam dari suatu gejala sosial tertentu.

Proses analisis data dalam penelitian ini adalah analisis yuridis kualitatif dengan penguraian secara deskriptif. Penentuan metode analisis seperti ini dilandasi oleh suatu pemikiran bahwa penelitian ini tidak hanya bermaksud menggambarkan (mendiskripsikan) data/objek penelitian sebagaimana apa adanya, melainkan juga bertujuan untuk memberikan argumentasi tentang Peran Penyidik Pangkalan TNI Angkatan Laut Tarempa Dalam Penanggulangan Pencurian Ikan Oleh Kapal Ikan Asing di Perairan Natuna.

\section{HASIL DAN PEMBAHASAN}

\section{Peran Penyidik Pangkalan TNI Angkatan Laut Tarempa dalam penanggulangan pencurian ikan oleh kapal asing di Perairan Natuna}

Maraknya pencurian ikan oleh kapal-kapal besar di wilayah kedaulatan Indonesia, perlu dilakukan suatu upaya untuk mengembalikan kepentingan kepentingan individu yang hilang akibat suatu tindak pidana yang terjadi. Penegakkan hukum adalah salah satu upaya yang ditempuh untuk menanggulangi sebuah kejahatan, sehingga kepentingan kepentingan individu yang hilang dapat dipulihkan. Untuk mengembalikan kepentingan kepentingan individu yang hilang merupakan tugas penguasa untuk memberikan kesejahteraan umum.

Dalam upaya untuk memberikan perlindungan terhadap sumber daya alam di wilayah perairan khsusnya perikanan. Penyidikan merupakan salah satu upaya untuk memberikan perlindungan tersebut. Dalam hal penyidikan tindak pidana dibidang perikanan menurut Pasal 73 Undang-Undang Nomor 45 Tahun 2009 Tentang Perubahan Undang-Undang No 31 Tahun 2004 yang selanjutnya disebut dengan UU Perikanan. Yang berhak melakukan penyidikan tindak pidana dibidang perikanan adalah sebagai berikut:

1. Penyidikan tindak pidana di bidang perikanan di wilayah pengelolaaan perikanan Negara Republik Indonesia dilaLukan oleh Penyidik Pegawai Negeri Sipil Perikanan, Penyidik Perwira TNI AL, dan/atau Penyidik Kepolisian Negara Republik Indonesia

2. Selain penyidik TNI Al, Penyidik Pegawai Negeri Sipil Perikanan berwenang melakukan penyidikan terhadap tindak pidana di bidang perikanan yang terjadi di ZEEI

3. Penyidikan terhadap tindak pidana di bidang perikanan yang terjadi di pelabuhan perikanan, diutamakan dilakukan oleh Penyidik Pegawai Negeri Sipil Perikanan.

4. Penyidik sebagaiman dimaksud pada ayat (1) dapat melakukan kordinasi dalam penangan penyidikan tindak pidana di bidang perikanan

5. Untuk melakukan kordinasi dalam penangan di bidang perikanan sebagaimana dimaksud apada ayat (4), Menteri membentuk Forum Kordinasi.

Dalam Pasal 73 menyebutkan bahwasanya yang berhak menjadi penyidik dalam tindak pidana di bidang perikanan adalah Penyidik Pegawai Negari Sipul Perikanan, Penyidik Perwira TNI AL, dan/atau Penyidik Kepolisian Negara Republik Indonesia TNI Angkatan Laut salah satu aparat yang berwenang yang berhak melakukan penyididkan tindak pidana di bidang 
perikanan yang terjadi di Zona Ekonomi Ekslusif Indonesia, yang dimaksudkan Zona Ekonomi Ekslusif Indonesia menurut Pasal 2 Undang Undang Nomor 5 Tahun 1983 tentang Zona Ekonomi Ekslusif Indonsia adalah Zona Ekonomi Eksklusif Indonesia adalah jalur di luar dan berbatasan dengan laut wilayah Indonesia sebagaimana ditetapkan berdasarkan undang-undang yang berlaku tentang perairan Indonesia yang meliputi dasar laut, tanah di bawahnya dan air di atasnya dengan batas terluar 200 (dua ratus) mil laut diukur dari garis pangkal laut wilayah Indonesia. Wilayah Zona Ekonomi Ekslusif Indonesia selain Penyidik Perwira TNI AL juga melibatkan Penyidik Pegawai Negeri Sipil Perikanan, dan untuk Pelabuhan Perikanan Penyidik Pegawai Negeri Sipil Perikanan menjadi yang utama dalam hal melakukan penyidikan.

Dengan banyaknya instansi yang memliki kewenangan penyidikan tindak pidana dibidang perikanan untuk itu diperlukan suatu kordinasi antar instansi yang berhak melakukan penyidikan, jika merujuk pada Pasal 73 ayat (4) dan (5) UU Perikanan, dibentuk sebuah kordinasi untuk penanganan penyidikan tindak pidana di bidang perikanan, kordiansi tersebut dibentuk oleh menteri yang bersangkutan, adapun menteri yang bersangkutan antara lain Menteri Kordinator Politik dan Hukum, Menteri Kordinator Kemaritiman, Menteri Kelautatan dan Perikanan, Kepala Staf Tentara Nasional Indonesia Angkatan Laut, Menteri Hukum dan Ham dan Menteri Keuangan.

Adanya landasan tersebut dibentuklah Badan Keamanan Laut (Bakamla), untuk memperkokoh keorganisasian Bakamla dibentuk Perpress No 178 Tahun 2014, namun dalam Perpres tersebut tidak atau belum menjelaskan kordinasi antara penyidik tindak pidana dibidang perikanan dalam melakukan penyidikan dibidang perikanan sehinga masih terjadi konflik kewenangan dalam melakukan penyidikan tindak pidana perikanan (Lufsiana, 2020).

Dalam TNI AL dalam melakukan penyidikan tindak pidana dibidang perikanan, Sesuai dengan Pasal 73 A UU Perikanan TNI AL berwenang untuk:

a. Menerima laporan atau pengaduan dari seseorang tentang adanya tindak pidana di bidang perikanan;

b. Memanggil dan memeriksa tersangka dan/atau saksi untuk didengar keterangannya;

c. Membawa dan menghadapkan seseorang sebaga tersangka dan/atau saksi untuk didengar keterangannya;

d. Menggeledah sarana dan prasarana perikanan yang diduga digunakan dalam atau menjadi tempat melakukan tindak pidana di bidang perikanan;

e. Menghentikan, memeriksa, menangkap, membawa, dan/atau menahan kapal dan/atau orang yang disangka melakukan tindak pidana di bidang perikanan;

f. Memeriksa kelengkapan dan keabsahan dokumen usaha perikanan;

g. Memotret tersangka dan/atau barang bukti tindak pidana di bidang perikanan;

h. Mendatangkan ahli yang diperlukan dalam hubungannya dengan tindak pidana di bidang perikanan;

i. Membuat dan menandatangani berita acara pemeriksaan;

j. Melakukan penyitaan terhadap barang bukti yang digunakan dan/atau hasil tindak pidana;

k. Melakukan penghentian penyidikan; dan 
1. Mengadakan tindakan lain yang menurut hukum dapat dipertanggungjawabkan.

Penyidikan adalah suatu proses yang penting dalam sistem peradilan pidana, karena dengan adanya penyidikan menjadi titik tolak untuk menentukan proses peradilan pidana, dan apabila penyidikan tidak berhasil sesuai yang diharapkan, maka proses peradilan pidana akan diberhentikan dan akan berdampak pada proses penegakkan hukum yang tumbul dan tidak dapat memulihkan hak-hak yang hilang atas tindak pidana yang terjadi.

TNI AL selaku aparat aparat penegakkan hukum laut khususnya tindak pidana dibidang perikanan dan juga sebagai komponen utama pertahanan negara matra laut sesuai dengan amanat Undang Undang Nomor 34 Tahun 2004 tentang Tentara Nasional Indonesia dalam Pasal 9 huruf b TNI AL memiliki tugas "menengakkan hukum dan menjaga kemanan di wilayah laut yuridiksi nasional sesau dengan ketentuan hukum nasional dan internasional yang telah diratifiasi.

Tugas penegakkan hukum dan menjaga keamanan mengandung arti bahwa TNI AL melaksanakan segala bentuk kegiatan yang berhubungan dengan penegakkan hukum di laut sesuai dengan ketentuan perundang-undangan yang berlaku untuk mengatasi ancaman tindakan kekerasan, ancaman naviasi serta pelanggaran hukum di wilayah laut yuridiksi nasional. Penegakkan hukum yang dilaksankan oleh TNI AL, terbatas dalam pengejaran, penangkapan, penyelidikan dan penyidikan perkara yang selanjutnya diserahkan kepada Kejaksaan. Dalam melaksanakan pengejaran terhadap kapal yang diduga cukup bukti melakukan tindak pidana inilah insiden penembakan dan/atau penenggelaman kapal biasa terjadi (Ketut Darmika, 2015).

Pada tahun 2015 menteri Kelautan dan Perikanan memberikan Instruksi untuk melakukan penenggalaman kapal baik ditengah laut maupun yang sita oleh pengadilan (CNN Indonesia, 2015). Instruksi Mentri Kelautan dan Perikanan tersebut sudah diatur dalam Pasal 69 ayat (4) UU Perikanan menyatakan bahwa: "Dalam melaksanakan fungsi sebagaimana dimaksud pada ayat (1) penyidik dan/atau pengawas perikanan dapat melakukan tindakan khusus berupa pembakaran dan/atau penenggelaman kapal perikanan yang berbendera asing berdasarkan bukti permulaan yang cukup.

Bukti permulaan yang cukup misalnya kapal perikanan berbendera asing tidak memiliki Surat Izin Penangkapan Ikan (SIPI) dan Surat Izin Kapal Penangkap Ikan (SIKPI), serta nyatanyata menangkap dan/atau mengangkut ikan ketika memasuki Wilayah Pengelolaan Perikanan Negara Republik Indonesia (WPP -NRI). Ketentuan ini menunjukkan bahwa tindakan khusus tersebut tidak dapat dilakukan sewenang-wenang, tetapi hanya dilakukan apabila penyidik dan/atau pengawas perikanan yakin bahwa kapal perikanan berbendera asing tersebut betul betul melakukan tindak pidana di bidang perikanan.

Selain dalam Pasal 69 ayat (4) Undang Undang Perikananan mengenai pemusnahan kapal diatur juga dalam Sema Nomor 1 Tahun 2015 tentang Barang Bukti Kapal dalam Tindak Pidana Perikanan bahwa peneggalaman dan pemusnahan kapal dilakukan sebagai berikut:

a. Bahwa terhadap Pasal 69 ayat (4) UU perikanan dalam melaksanakan fungsi sebagaimana dimaksud pada ayat (1) penyidik dan/atau pengawas perikanan dapat melakukan tindakan khusus berupa pembakaran dan/atau penenggelaman kapal perikanan yang berbendera asing berdasarkan bukti permulaan yang cukup, terhadap penggunanan 
Pasal 69 ayat (4) ini, ketua Pengadilan Negeri tidak mempunyai kewenangan untuk memberikan persetujuan.

b. Bahwa kapal yang terlibat dalam kejahatan pencurian ikan dilaut yang telah disita oleh penyidik secara secara sah menurut hukum dan dijadikan barang bukti maka apabila hendak dimusnahkan atau dilelang, penyidik harus meminta persetujuan Ketua Pengadilan Negeri setempat Pasal 76 huruf A Undang Undang Perikanan Juncto Pasal 38, Pasal 45 Undang Undang Nomor 8 Tahun 1981 Tentang Kitab Undang Undang Hukum Acara Pidana (KUHAP)

c. Apabila Perkara telah dilimpahkan ke Pengadilan Tingkat Pertama, Banding dan Kasasi maka persetujuan pemusnahan diterbitkan oleh ketua yang bersangkuta, namun apabila perkara telah dilimpahkan kepada Majelis, maka persutujuan pemusnahan diterbitkan oleh Majelis Hakim yang bersangkutan.

Sebenarnya dalam hal pengelolan barang bukti kapal pelaku tindak pidana dibidang perikanan juga memiliki alternatif lain, dimana menurut Pasal $76 \mathrm{C}$ ayat bahwasanya dalam hal pengelolaan barang bukti dapat dilakukan dengan pelelangan dengan persetujuan ketua pengadilan negeri dan kemudian hasil pelelangan tersebut disetor negara dan dapat juga diserahkan kepada kelompok usaha bersama nelayan dan/atau koperasi perikanan.

Penenggalaman/pemusnahaan kapal timbul pro-kontra didalam masyarakat, ada terdapat lima alasan kenapa kebijakan tersebut justru layak didukung:

1) Tidak ada negara di dunia ini yang membenarkan tindakan warganya yang melakukan kejahatan di negara lain. Kapal asing yang ditenggelamkan merupakan kapal yang tidak berizin untuk menangkap ikan di wilayah Indonesia, sehingga disebut tindakan kriminal.

2) Tindakan penenggelaman dilakukan di wilayah kedaulatan dan hak berdaulat Indonesia (zona ekonomi eksklusif).

3) Tindakan penenggelaman dilakukan atas dasar ketentuan hukum yang sah, yaitu Pasal 69 ayat (4) UU Perikanan.

4) Indonesia mengalami kerugian, jika tindak pidana pencurian ikan dibiarkan maka kerugian akan semakin membesar.

5) Proses penenggelaman telah memperhatikan keselamatan para awak kapal.

Di sisi lain kebijakan penenggelaman/pemusnahan kapal tersebut juga menimbuka pendapat yang tak menyetujui kebijakan tersebut, berpendapat bahwasanya dengan adanya penenggelaman/pemusnahan kapal tersebut adalah tindakan sembrono tanpa memandang manfaat dari penenggalaman kapal tersebut, padahal pemberian ke kelompok nelayan lebih bermanfaat dan dibandingkan dengan penenggalaman kapal yang hanya menjadi "sampah" di lautan.

Tindakan penenggalaman/pemusnahan kapal telah sering terjadi pada tahun 2017 di Kepulauan Natuna sebanyak 13 Kapal. Indonesia merupakan negara kepulauan yang memiliki sumber daya yang besar khsususnya dibidang perikanan, namun pemanfaatan perikanan belum maksimal karena maraknya tindak pidana dibidang perikana di laut Indonesia sehingga membutuhkan upaya hukum lebih maksimal dalam menanggulangi tindak pidana tersebut. 


\section{Kendala yang dihadapi dalam melaksanakan penanggulangan pencurian ikan oleh kapal asing di Perairan Natuna dan upaya mengatasinya}

Tindak pidana Illegal Fishing juga merupakan pelanggaran atas UndangUndang Dasar 1945 Pasal 33 ayat (3) dan aturan kepidanaannya dirumuskan dalam Pasal 262-265 ayat (4) KUHP Tentang Kejahatan Pencurian, dengan hukuman terberatnya adalah hukuman mati atau pidana seumur hidup atau selama waktu tertentu paling lama dua puluh tahun, pelaku tindak pidana Illegal Fishing juga dapat dijerat Pasal 187 KUHP dengan berdasarkan akibat yang ditimbulkan. Ketentuan pidana dalam dalam UU No. 31 Tahun 2004 tentang Perikanan, yang telah diubah dengan UU No. 45 Tahun 2009, beragam mulai dari 100 juta hingga 20 miliar rupiah. Belum lagi pidana penjara yang bervariasi mulai dari satu tahun hingga enam tahun.Faktanya, begitu banyak terdakwa kasus perikanan yang diganjar hukuman ringan (Gatot Supramono, 2011:194).

Pembuktian negative pada sistem peradilan pidana Indonesia lebih dominan untuk penanganan suatu peristiwa pidana. Dengan demikian keberadaan alat bukti sebagai dasar dimulainya proses sistem peradilan pidana, sedangkan dalam hal kasus pencurian ikan sangat sulit menerapkan beban pembuktian untuk menjerat para pelaku yang melaksanakan praktek Illegal Fishing.

Kesulitan untuk mencari alat bukti inilah yang menyebabkan para penyidik mengalami kendala untuk menjerat pelaku Illegal Fishing, karena dalam pembuktian negative penyidik harus terlebih dahulu membuktikan ada tidaknya unsur kesalahan yang mengarah ke perbuatan pidana Illegal Fishing untuk dimintai pertanggungjawaban.

Hal ini sebagaimana dimuat dalam peraturan perundang-undangan atau yang disebut asas culpabilitas atau sebutan lain terhadap asas tiada hukuman tanpa kesalahan yang dikenal dalam hukum pidana. Unsur kesalahan dari pelaku tindak pidana dapat berupa kesengajaan (opzet) atau kelalaian (culpa) hukum pidana materil bahwa pidana hanya diberikan kepada orang yang bersalah (asas "culpabilitas", tiada pidana tanpa kesalahan). Oleh karena itu penyidik harus dapat membuktikan adanya unsur kesalahan yang dapat berupa kesengajaan atau kelalaian dalam rangka menjerat pelaku kejahatan Illegal Fishing.

Penerapan Pasal 56 ayat (1) KUHP yang mengkualifikasikan pelaku tindak pidana sebagai orang yang melakukan, yang menyuruh melakukan dan yang turut serta melakukan perbuatan pidana dapat juga diterapkan dalam kejahatan Illegal Fishing yang melibatkan banyak pihak. Namun demikian beban pidana yang harus ditanggung secara bersama dalam terjadinya tindak pidana Illegal Fishing juga dapat mengurangi rasa keadilan masyarakat, karena dengan kualitas dan akibat perbuatan yang tidak sama terhadap pelaku turut serta, dapat dipidanakan maksimum sama dengan si pembuat menurut ketentuan Pasal 56 ayat (1) KUHP, sedangkan ternyata peranan pelaku utamanya sulit ditemukan. Demikian juga belum diatur tentang sanksi pidana bagi Korporasi serta sanksi pidana tambahan terutama kepada tindak pidana pembiaran.

Lemahnya Koordinasi Antar Penegak Hukum dapat menimbulkan tumpang tindih kewenangan dan kebijakan masing-masing, sehingga sangat rawan menimbulkan konflik 
kepentingan. Penegakan hukum yang tidak terkoordinasi merupakan salah satu kendala dalam penanggulangan kejahatan Illegal Fishing.

Proses peradilan mulai dari penyidikan hingga ke persidangan membutuhkan biaya yang sangat besar, proses hukum yang sangat panjang dan sarana / prasarana yang sangat memadai membutuhkan keahlian khusus dalam penanganan kasus tersebut. Dalam satu Instansi tentu tidak memiliki semua komponen, data/informasi ataupun sarana dan prasarana yang dibutuhkan dalam rangka penegakan hukum. Oleh karena itu selain profesionalisme penyidik diperlukan koordinasi dan kerjasama yang sinergis antar Instansi yang terkait dalam upaya penegakan hukum terhadap Illegal Fishing tersebut.

Koordinasi antar berbagai Instansi tersebut sangat menentukan keberhasilan dalam penegakan hukum pidana terhadap kejahatan Illegal Fishing yang merupakan kejahatan terorganisir yang memiliki jaringan yang sangat luas mulai dari penangkapan ikan secara ilegal, tanshipment ikan ditengah laut hingga eksport ikan secara ilegal.

Permasalahan di atas salah satunya adalah tidak semua perwira TNI AL adalah penyidik tindak pidana di laut. Penyidik tindak pidana dilaut adalah seorang perwira yang mempunyai kualifikasi sebagai seorang penyidik dan telah disumpah berdasarkan skep pangab Nomor skep/907/XII/1987 tanggal 23 Desember 1987 tentang penunjukkan perwira TNI angkatan laut selaku pejabat penyidik perkara tindak pidana tertentu dilaut.

Namun demikian kemampuan personil yang berstatus sebagai penyidik yang berada di KRI atau pangkalan tidak semuanya berkualifikasi sarjana hukum sehingga kemampuannya dalam melakukan penyidikan masih terbatas, kaitannya kemampuan dalam hal hukum formil dan hukum materiil. Dengan demikian peran penyidik TNI AL dalam penegakan hukum Illegal Fishing di ZEEI masih belum optimal, walaupun untuk meningkatkan kemampuan personil dalam bidang penyidikan dari TNI AL telah melakukan beberapa langkah yaitu seperti :

1. Memberikan pembekalan tentang materi kamla pada saat menjadi siswa pembentukan dan pengembangan.

2. Melakukan kursus-kursus tentang kekamlaan yang dilaksanakan di linkup TNI AL.

3. Melaksanakan kursus-kursus perwira penyidik di laut (Suspaidikla)

4. Melaksanakan round table discussion berkaitan dengan permasalahan kamla.

Temu teknis penegak hukum seluruh Indonesia antar instansi terkait untuk menyamakan persepsi penyidikan.

\section{PENUTUP}

Berdasarkan hasil penelitian dan pembahasan, maka dapat disimpulkan Peran Penyidik Pangkalan Tni Angkatan Laut Dalam Penanggulangan Pencurian Ikan Oleh Kapal Ikan Asing Di Perairan Natuna adalah sebagai berikut ;

1. Peran Penyidik Pangkalan TNI Angkatan Laut Tarempa dalam pencurian ikan oleh kapal ikan asing di Perairan Natuna adalah melakukan penyidikan sesuai dengan kewenangannya menurut Pasal 73 UU Perikanan. Penegakkan hukum yang dilaksankan 
oleh TNI AL, terbatas dalam pengejaran, penangkapan, penyelidikan dan penyidikan perkara, dan selanjutnya perkara diserahkan kepada Kejaksaan. Dalam melaksanakan pengejaran terhadap kapal yang diduga cukup bukti melakukan tindak pidana inilah insiden penembakan dan/atau penenggelaman kapal biasa terjadi.

2. Kendala yang dihadapi oleh penyidik Tentara Nasional Indonesia Angkatan laut dalam melaksanakan penegakkan hukum terhadap pelaku tindak pidana di bidang perikanan adalah kurangnya sarana dan prasarana khusunya alutista untuk melakukan pengawasan di wilayah perikanan Indonesia, anggaran dana khusus guna untuk pemanggilan saksisaksi, ahli dan juga untuk pemberkasan, penenggalaman/pemusnahan kapal dan lain lain.

\section{DAFTAR PUSTAKA}

Andi Hamzah, Hukum Acara Pidana Indonesia, Sinar Grafika, Jakarta, 2004

Andi Sofyan dan Abdul Asis, Hukum Acara Pidana (Suatu Pengantar), Kencana Prenadamedia Group, Jakarta, 2000

Barda Nawawi Arief, Bunga Rampai Kebijakan Hukum Pidana Perkembangan Penyusunan Konsep KUHP Baru, Cetakan ke-1, Kencana Prenada Media Group, Jakarta, 2008

Camelia Sukmawati (et.al,),Laksamana Kent, Gagasan, Tindakan dan Harapan Bernard Kent Sondakh, PT. Gramedia Pustaka Utama, Jakarta, 2014

Djoko Tribawono, Hukum Perikanan Indonesia, Edisi Kedua (Revisi), PT Citra Aditya Bakti, Bandung, 2013.

Franz Magnis Suseno, Etika Politik Prinsip-prinsip Moral Dasar Kenegaraan Modern, Gramedia, Jakarta, 1994

H. Salim dan Erlies Septiana Nurbani, Penerapan Teori Hukum pada Penelitian Tesis dan Disertasi, PT.RajaGrafindo Persada, Jakarat, 2013

I Made Pasek Diantha, Zona Ekonomi Eksklusif Indonesia, Mandar Maju, Bandung, 2002.

Lawrence M. Friedman, American Law, W.W Norton And Company, New York, $1984 .$.

R. Subekti, Hukum Pembuktian, Pradnya Paramita, Jakarta, 1978.

R. Subekti dan R Tjitro Soedibia, Kamus Hukum, Pradya Paramita, Jakarta, 2000.

Satjipto Raharjo, Ilmu Hukum, PT. Citra Aditya Bakti, Bandung, 2000.

Soerjono Soekanto, Pengantar Penelitian Hukum, Universitas Indonesia (UI-Press), Jakarta, 1984..

Wirjono Projodikoro, Hukum Acara Pidana Indonesia, Penerbit Alumni, Bandung, 2007.

Fitiyadi, Perspektif Pendaratan Ikan, Majalah Forum Hukum, Volume 4 No. 1, 2007.

Untung Suropati, Wilayah Perbatasan Masih Rawan Konflik, Maritime Magazine,Edisi 18/Tahun II/Maret 2012

Achmad Ali, Menguak Teori Hukum (Legal Theory) dan Teori Peradilan (Judicialprudence) termasuk Interpretasi Undang-Undang (Legisprudence), Volume I, Pemahaman Awal, Cetakan ke-4, Kencana, Jakarta, 2012 
Abhy Maulana, Penegakan Hukum Di Indonesia, dikutip dari http://abhymaulanainitulisanku.blogspot.com.,

Elfirah Rosalina, Illegal Fishing http://firarosalina.blogspot.com/2012/10/ illegal-fishing.html

Harian Umum Pelita, Negara Rugi Akibat Rp30 Triliun Akibat IUU Fishing, (04/04/2015) http://www.pelita.or.id/baca.php?id=47023

Jieanggie, Penegakan Hukum di Indonesia, http://www.jieanggie.blogspot.com/2012/03/penegakan-hukum-di-Indonesia_17.html

Jimly Asshiddiqie, Penegakan Hukum, hlm. 1, yang dikutip dari http://www.docudesk.com,

Nina Suartika, Doktrin Poros Maritim Tingkatkan Wibawa Indonesia, (03/07/2014), http://www.pemilu.okezone.com/.../doktrin-poros-maritim-tingkatkan-wibawa-Indonesia

Undang-Undang Dasar Negara Republik Indonesia Tahun 1945.

Undang-Undang Nomor 1 Tahun 1946 tentang KUHP.

Undang-Undang Nomor 8 Tahun 1981 tentang KUHAP.

Undang-Undang Nomor 5 Tahun 1983 tentang ZEEI.

Undang-Undang Nomor 17 Tahun 1985 tentang Pengesahan United Nations Convention on the Law of the Sea (UNCLOS 1982)

Undang-Undang Nomor 6 Tahun 1996 tentang Perairan Indonesia

Undang-Undang Nomor 31 Tahun 2004 tentang Perikanan.

Undang-Undang Nomor 34 Tahun 2004 tentang Tentara Nasional Indonesia

Undang-Undang Nomor 45 Tahun 2009 tentang Perubahan Atas Undang-Undang Nomor 31 Tahun 2004 tentang Perikanan. 